\title{
Determinants of Real Exchange Rate: Case of Jordan
}

\author{
Dalia Ibrahim Mustafa \\ Department of Islamic Banking, School of Shari'a, The University of Jordan, Amman, Jordan
}

\section{Email address:}

Dalia.mustafa@ju.edu.jo

\section{To cite this article:}

Dalia Ibrahim Mustafa. Determinants of Real Exchange Rate: Case of Jordan. International Journal of Business and Economics Research. Vol. 8, No. 6, 2019, pp. 375-381. doi: 10.11648/j.ijber.20190806.17

Received: October 5, 2019; Accepted: October 22, 2019; Published: October 29, 2019

\begin{abstract}
This paper aims to investigate the determinants of real exchange rate in Jordan, four determinants were chosen which are; governmental expenditures, foreign reserves, workers' remittances receipts and term of trade. Time series quarterly data were collected for the period of 2000-2017. The unit root tests and Johansen's coingetration were performed to find that there is a long relationship among the variables of this study. Then VECM was tested to find a long-run causality running the determinants to RER equilibrium which can be reached within 3 quarters. Also, it can be endorsed that government expenditures can negatively affect RER in significance, both in short-run and long-run dynamics. However, three other variables of the study have positive and lower association with RER. The results imply an opportunity to enhance the real exchange rate through monitoring the governmental spending, and setting a policy to encourage the migrants to increase their remittances they send home. The foreign reserves are necessary to stabilize RER. However, TOT is also affected by RER, when exchange rate rises it suggests lowering the prices of the domestic goods and services, however, it may not affect the prices of the exported commodities. Therefore, there were possibilities for several corrective policy actions to reduce the misalignment in real exchange rate. Thus it is suggested that the capital government spending should concentrate more on capital expenditures, and to follow the track of trade liberalization in tendency to depreciate RER. Also, workers' remittances should be encouraged to promote economic development through increasing the opportunity for household investments.
\end{abstract}

Keywords: Real Exchange Rate, Governmental Expenditures, Foreign Reserves, Workers' Remittances Receipts, Term of Trade, Vecm, Jordan

\section{Introduction}

One of the major factors that affect a country's relative level of economic growth is the real exchange rate (RER). RER plays a critical role in international trade among countries; it is a key element in any open economy, keeping in mind the fluctuation in RER is natural according to the volatility in the macroeconomic variables. Furthermore, RER is a vital factor in attaining the objectives of monetary policy.

Several papers were conducted on developed and developing countries to examine the association between RER and the economic fundamentals. However the RER volatility in developing countries is found to be more than in developed ones. Developing countries may need to choose fixed exchange regime or a flexible one that may provide the economy with sustainable level of RER. Hence; it is one of the topics that are considered debatable worldwide.

Edwards (1988) started one of the first studies handling the behavior of RER through formulating a dynamic model over 12 developing countries. Among the results the paper presented; RER is affected by governmental expenditures and terms of trade among other macroeconomic variables. Similarly other studies revealed that Government expenditures negatively affect RER [16, 18, 3, 19]. The results of cointegration analysis showed there is a long run equilibrium association among the variables. In addition, the error correction model (ECM) coefficients from the short run dynamics indicated the movement toward the long-run equilibrium. Therefore, monitoring the governmental spending through the monetary policy may have a direct effect on stabilizing RER.

Even developed countries showed similar results regarding the nature of the association between government expenditures and RER; an investigation of the long-run determinants of RER was applied [20]. Among of the factors considered in the study; governmental expenditures were tested on Canadian data covering 1972-2010 period of time. 
The results showed that there is a cointegration relationship. However, in the short run the governmental expenditures do not have any significant impact on growth of RER. Moreover, the impulse response test proved that RER will depreciate for a shock to the governmental spending.

On other hand, several empirical studies showed through different methodologies that an improvement in TOT leads to appreciation in RER in the long run, [1, 23, 21, 11, 18]. It was concluded that the overvaluation of a currency is unfavorable phenomenon especially for the international competitiveness and to eliminate the risk of currency risk. In Contrary, an adverse result regarding to the effect of TOT on RER was found in Pakistan [7]. The results confirmed that TOT is causing RER to depreciate in Pakistan. One of the suggestions they have that depreciating RER may encourage the exports to enhance, however that it might occur in account of debt. Regarding Jordan, the appreciation in the REER is not caused by the international competitiveness as the traditional theory explains. Therefore, it was recommended to design economy policies that aim to stabilize the real exchange rate is possible [4].

In terms of the effect of Workers' remittances on RER; the RER appreciates if the remittances receipts of the workers increase $[5,18,25,7]$. When Workers' remittances increase the receiving economy benefits and that will lower the competitiveness of exported commodities in tradable sectors. Undesired problems may initiate when the flow of remittances are large relatively to the recipient countries such as what noted in Latin America countries- [22], the more workers' remittance the more tendency to spend on leisure, hence, wealth will be distributed unevenly among the sectors in the economy. Moreover, the less developed countries confirmed a "Dutch Disease" effect as a result of increase in workers' remittances [17]. In contrary, other studies demonstrated that RER is a significant determinant of workers' remittances [15].

On other hand, the foreign reserves have positive relation to RER, and that matches the theories [1]. Even the Granger causality test revealed that in the long run the foreign reserves causes RER, nonetheless, in the short run the result was unidirectional [24]. The impact of foreign reserves on RER is more important for Asian countries and the ones with exporting natural resources [2]. Moreover, the foreign reserves were considered as a proxy of government intervention in exchange rate and that is an evidence of effect of the reserves on RER [27]. Country creditworthiness is measured by the changes in foreign reserves [9].

For the remainder of this paper; the determinants of RER in Jordan -the ones used in the methodology of this paperwill be provided with brief overview in Jordan. The data, variables and test results are thoroughly illustrated then. Finally conclusion and some implications are outlined.

\section{Determinants of RER in Jordan}

There are many determinants for RER, and those determinants vary from one country to another regarding to the country's macroeconomic environment, political atmosphere, its resources and many other factors. According to this paper, four determinants are chosen to be tested and were supported by empirical evidences of previous studies.

\subsection{Governmental Expenditures}

Jordan-as a developing country- depends on both current expenditures and capital ones. The growth of governmental expenditures -hence the growth of Jordanian economy- is apparent throughout years with the highest record in 2011 and 2012. This increase in governmental spending is related to the increased redistribution of income in the society.

\subsection{Foreign Reserves}

As known, foreign reserves are the country's holding of gold and tradable foreign currencies. The central banks have those reserves to balance the payments from one period to another. In Jordan, foreign reserves are increasing gradually 2000-2010, and then they dropped till 2012, to get back rising in 2013. Knowing that Jordan follows the fixed exchange rate, foreign reserves are highly important element to peg the exchange rate, and thus it would affect it.

\subsection{Worker Remittances Receipts}

Are the money sent by who work abroad to his/her family in home country. Those remittances along with international aids are considered the major source of foreign financial inflows. In 2012, according to the World BankReport, \$401 billion went to developing countries (a new record) with overall global remittances at $\$ 514$ billion. Usually those remittances go to private sector which it tends to consume commodities, and save if it is possible.

\subsection{Terms of Trade (TOT)}

Is a ratio between the prices of exports divided by the price of imports. TOT fluctuates regarding the movements of the import and export prices. If for instance export prices increase this yields to increase in export quantities then the production of the export sector would increase, and it is expected as a result the wages of the export sector increase as well. The increase of individual income may increase the consumption, hence the price of the goods would increase which leads to increase in RER. In Jordan, TOT fluctuates in over time, it started to steeply increase after the mid of 2007 to hit the peak in the second half of 2008, then gradually dropped back to its average level in the mid of 2010, keeping fluctuating within a narrow range.

\section{Data, Variables and Econometric Analysis}

In this study, quarterly time series data for Jordan from 2000-2017 have been collected from the Central Bank of Jordan. The main variables of this study are; real exchange rate, governmental expenditures, foreign reserves, workers' 
remittances receipts, and terms of Trade (TOT).

To calculate the real exchange rate (RER), PPP approach is used, as follows;

$$
R E R=N E R *\left(\frac{U S_{-} C P I *}{J_{-} C P I}\right)
$$

Where NER is the nominal exchange rate, US CPI is consumerprice index for US. And J_CPI is the consumer price index for Jordan. While all the explanatory variables -except TOT- are calculated as a percentage of Real Gross Domestic Product (RGDP), to make it consistent with RER values.

\subsection{Descriptive Diagnostics and Correlation}

Table 1 shows the descriptive statistics for the variables of the study which are. The descriptive measures include; mean, median, maximum, minimum, standard deviation, skewness, Kurtosis, and number of observations.

Table 1. The descriptive statistics for the main variables of the study.

\begin{tabular}{llllll}
\hline & RER & Expenditures & Reserves & Rem & TOT \\
\hline Mean & 0.727 & 0.711 & 3.091 & 0.257 & 0.776 \\
Median & 0.703 & 0.715 & 3.199 & 0.254 & 0.744 \\
Maximum & 0.847 & 1.065 & 4.444 & 0.301 & 1.438 \\
Minimum & 0.653 & 0.435 & 2.032 & 0.223 & 0.573 \\
Std. Dev. & 0.0666 & 0.147 & 0.760 & 0.019 & 0.161 \\
Skewness & 0.659 & 0.111 & 0.047 & 0.411 & 2.025 \\
Kurtosis & 1.898 & 2.474 & 1.597 & 2.479 & 7.756 \\
Observations & 56 & 56 & 56 & 56 & 56 \\
\hline
\end{tabular}

This table shows the descriptive statistics of the following variables; RER (Real Exchange Rate), Governmental Expenditures (Expenditures), workers' remittances receipts (REM), foreign reserves (RESERVES), and terms of trade (TOT).

As it appeared above that the mean and the median of the variables are close to each other, except foreign reserves that were reflected in high standard deviation. In terms of skewness, governmental expenditures, foreign reserves and remittances receipts are considered fairly symmetrical, while TOT is highly skewed to the right. Noticing kurtosis ${ }^{1}$, it is apparent that all variable have lighter tails in their distribution in comparison to normal distribution except TOT which has a very heavy tails. Those results were definitely affected by sample size of this study which consists of only 56 observations.

In table 2 the correlation results are shown. The correlation indicates the strength of association and the direction of it between the underlying variables. It takes values between two extreme values which are -1 and +1 , when the correlation goes toward zero it indicates of very weak relation.

Table 2. Correlations between RER and the fundamental variables.

\begin{tabular}{llllll}
\hline Variables & RER & Expenditures & $\begin{array}{l}\text { Foreign } \\
\text { Reserves }\end{array}$ & $\begin{array}{l}\text { Remittance } \\
\text { Receipts }\end{array}$ & TOT \\
\hline RER & 1 & - & - & - & - \\
Gov. Exp. & -0.712 & 1 & - & - & - \\
Reserves & 0.741 & 0.498 & 1 & - & - \\
\hline
\end{tabular}

1If Kurtosis is above 3 then the data distribution is heavy in tails comparing to the normal distribution, and if kurtosis less than 3 then the data distribution is lighter in tails comparing to the normal distribution.

\begin{tabular}{llllll}
\hline Variables & \multirow{2}{*}{ RER } & Expenditures & $\begin{array}{l}\text { Foreign } \\
\text { Reserves }\end{array}$ & $\begin{array}{l}\text { Remittance } \\
\text { Receipts }\end{array}$ & TOT \\
\hline REM & 0.132 & -0.249 & -0.1028 & 1 & - \\
TOT & 0.257 & -0.158 & -0.256 & 0.407 & 1 \\
\hline
\end{tabular}

This table shows the correlation results of the following variables; RER (Real Exchange Rate), Governmental Expenditures (Gov. Exp.), workers' remittances receipts (REM), foreign reserves (RESERVES), and terms of trade (TOT)

As it appeared in the table the correlation between RER and all the other variables are positive except for governmental expenditures, the correlation with governmental expenditures are high and negative, while foreign reserves are significantly positive. TOT and workers' remittances receipts have lower correlation with RER. All these results are discussed shortly.

\subsection{Unit root Results}

The researcher tests for the order of integration of the variables under consideration. Thus, two unit root tests were conducted as shown in table 3 below. Unit root test is important to ensure that the variables included in the model are a constant mean and constant variance. This makes prediction of future values sensible. When the variables are non-stationary, as expected for most of the macroeconomic variables, cointegration is used to investigate the relationship. The idea is to test if a long run relationship can be built among the variables that are non stationary.

Augmented Dickey Fuller (ADF) and Philips-Perron (PP) are used to test the unit root in the data of this study's variables. Both of those tests rely on the t-statistics for the coefficient of the lagged dependent variable compared with special calculated critical values. If the calculated value is greater than critical value, then the null hypothesis of a unit root is rejected; the unit root does not exist, and the variable is stationary.

Table 3 shows the results of the tests, it shows that variables at level are non-sationary under ADF test. However, by looking at PP results it states that remittances receipts and governmental expenditures are stationary at level. By taking the first difference; ADF and PP tests rejected the null hypothesis for, RER, RESERVES, and TOT.

\subsection{Cointegation Test Results}

After testing the stationarity of the variables, Cointegration test is used for estimating a long-run relationship between time series macroeconomic variables. In addition, it suggests that the time series cannot move far away from one another.

There are several tests for cointegration, this study applied Johanson Cointegration test, and this test requires the variables of the model to be integrated of the same order ${ }^{2}$. The non-stationary time series variables of the study were not all integrated at the first difference and they are tend to drift apart in the long run and may obtain a spurious relationship. Two steps needed to apply this test; first the best possible line

2According to ADF test, all variables are stationary at the first difference. 
is estimated and residuals are collected. Then the unit root stationary then a long term relationship exists. test is used to test whether residuals are stationary. If they are

Table 3. Unit root results.

\begin{tabular}{lllllll}
\hline \multirow{2}{*}{ Variable } & ADF & \multicolumn{5}{c}{ At first difference } \\
\cline { 2 - 7 } & At level & Intercept \& trend & none & intercept & Intercept \& trend & none \\
\cline { 2 - 8 } & intercept & -1.282 & $-1.804 *$ & $* * *-5.457$ & $* * * 5.550$ & $* * *-5.108$ \\
\hline RER & 1.361 & -1.914 & 1.294 & $* * *-11.867$ & $* * *-11.823$ & $* * *-11.617$ \\
Gov. exp. & -1.396 & -1.644 & -0.289 & $* * *-3.929$ & $* * *-8.714$ & $* * *-3.964$ \\
REM & -1.772 & -1.814 & 0.045 & $* * *-6.218$ & $* * *-6.196$ & $* * *-6.247$ \\
Reserves & -1.515 & -2.294 & -0.564 & $* * *-6.269$ & $* * *-6.22$ & $* * *-6.334$ \\
TOT & -1.9125 & & & & & \\
\hline
\end{tabular}

Table 3. Continued.

\begin{tabular}{lllllll}
\hline \multirow{2}{*}{ Variable } & PP & & & & & \\
& At level & & & At first difference & \\
\cline { 2 - 7 } & Intercept & Intercept \& trend & none & intercept & Intercept \& trend & none \\
\hline RER & -1.618 & -0.726 & $* * *-2.704$ & $* * *-5.457$ & $* * *-5.544$ & $* * *-5.143$ \\
Gov. exp. & $* * *-5.909$ & $* * *-10.683$ & 0.122 & $* * *-46.485$ & $* * *-48.507$ & $* * *-37.642$ \\
REM & $* *-3.469$ & $* *-3.946$ & -0.510 & $* * *-10.838$ & $* * *-11.359$ & $* * *-10.921$ \\
Reserves & -1.726 & -2.236 & -0.032 & $* * *-6.215$ & $* * *-6.191$ & $* * *-6.244$ \\
TOT & -1.913 & -2.463 & -0.581 & $* * *-6.269$ & $* * *-6.225$ & $* * *-6.334$ \\
\hline
\end{tabular}

This table shows the unit root tests which are ADF (Augmented Dickey Fuller) and PP (Philips-Perron) of the following variables; RER (Real Exchange Rate), Governmental Expenditures (Gov Exp.), workers' remittances receipts (REM), foreign reserves (RESERVES), and terms of trade (TOT).

Table 4 presents the results of cointegration test. The lag length of the cointegration test is selected by nonautocorrelation of error term. Thus, the optimal lag length that is selected is 3 (i.e. lag $=3$ ). According to the results based on Johansen's test, the null hypothesis of no cointegration $(\mathrm{r}=0)$ can be rejected using the maximum eighenvalue or trace test statistics. Those tests are used to examine the rank $r$, where $r$ stands of $r$ the number of cointegrasting relations (or cointegrating vectors). This implies the existence of long-term causality. However, the direction is not yet clear. According to the table above, Trace test indicates 3 cointegrating equations at $5 \%$. Thus, the researcher can conclude the model of the variables represents a long-run relationship between the variables does exist.

Table 4. Results of Johansen's Cointegration test.

\begin{tabular}{|c|c|c|c|c|}
\hline & Trace stastic & 0.05 Critical Value & Max Eighnvalue & 0.05 Critical value \\
\hline $\mathrm{r}=0$ & $123.634 * * *$ & 69.819 & $57.567 * * *$ & 33.877 \\
\hline$r \leq 1$ & $66.068 * * *$ & 47.856 & $28.486^{* *}$ & 27.584 \\
\hline$r \leq 2$ & $37.582 * * *$ & 29.797 & $24.608 * *$ & 21.131 \\
\hline
\end{tabular}

$*, * *, * * *$ denote significance level at $10 \%, 5 \%$ and $1 \%$ respectively.

Lag length selection: non-autocorrelation error terms, Number of lags $=3$

\subsection{Vector Error Correction Model (VECM)}

Once the cointegration among the variables is found, Error Correction Model is used. It considers a short run model that serves several issues; first it can confirm the results of the long-run analysis (the results of the cointegration test). Second; it is used to check whether the impact of the independent variables is transitory or permanent. ECM provides an insight of the speed of the adjustment in response to a deviation from the long-run equilibrium, which can be used in policy setting. Granger and Engle (1987) suggested ECM as follows:

$$
\Delta y_{t}=\alpha_{0}+\alpha_{y} e_{t-1}+\alpha_{1} \Delta z_{t}+\epsilon
$$

Where $\alpha_{0}$ is the constant, $\alpha_{y}$ is coefficient of the ECM term, $\alpha_{1}$ is the coefficient of the independent variable, and $\in$ is the error term. All regressors are expressed in first difference, except the ECM term. ECM term is a 3 lags of residual obtained from the cointegration equation. Table 5 shows the results of ECM. Then the serial correlation was tested to ensure of not having a repeating patterns in the data. Then Heteroskedasticity and stability were also the results of data diagnosis is presented at the end of the table.

Table 5. Vector Error Correction Estimates Model (VECM) Results.

\begin{tabular}{llll}
\hline Variables & Coefficient & Std. Error & t-statistics \\
\hline \multicolumn{2}{l}{ Estimates of the cointegration relationship } \\
RER (-1) & 1 & & \\
EXP (-1) & $0.555^{* * * *}$ & 0.022 & 25.331 \\
RES (-1) & -0.000 & 0.004 & -0.049 \\
REM (-1) & $0.594 * * *$ & 0.182 & 3.270 \\
TOT (-1) & $-0.085^{* * *}$ & 0.017 & -5.129 \\
C & 1.206 & & \\
Short-run Dynamics & & \\
ECT & $-0.323 * * *$ & 0.0773 & -4.178 \\
D (RER (-1)) & 0.047 & 0.135 & 0.3344 \\
D (RER (-2)) & $0.235^{*}$ & 0.127 & 1.847 \\
D (RER (-3)) & $0.305^{* *}$ & 0.132 & 2.319 \\
D (Exp (-1)) & $0.112 * * *$ & 0.039 & 2.868 \\
D (Exp (-2)) & 0.046 & 0.031 & 1.492 \\
\hline
\end{tabular}




\begin{tabular}{llll}
\hline Variables & Coefficient & Std. Error & t-statistics \\
\hline D (Exp (-3)) & 0.016 & 0.016 & 0.967 \\
D (RES (-1)) & -0.001 & 0.004 & -0.325 \\
D (RES (-2)) & 0.006 & 0.004 & 1.464 \\
D (RES (-3)) & 0.001 & 0.004 & 0.186 \\
D (REM (-1)) & 0.003 & 0.109 & 0.030 \\
D (REM (-2)) & -0.134 & 0.087 & -1.537 \\
D (REM (-3)) & -0.0551 & 0.086 & -0.638 \\
D (TOT (-1)) & $0.025^{*}$ & 0.013 & 1.892 \\
D (TOT (-2)) & $0.031^{* *}$ & 0.013 & 2.454 \\
D (TOT (-3)) & -0.001 & 0.012 & -0.100 \\
C & $-0.003^{* *}$ & 0.001 & -2.311 \\
R-Squared: & 0.685 & F-Statistics: & 4.751 \\
Adj. R-squared: & 0.541 & Log likelihood: & 200.7040 \\
Standard error: & 0.006 & Akaike AIC: & -7.066 \\
\hline
\end{tabular}

Diagnostic tests:

Serial Correlation LM test 7.164 [0.067]

HeteroskedasticityBreusch-Pagan-Godfrey test 30.795 [0.058]

Normality test, Jarque-Bera test 0.347 [0.841]

This table shows the results of VECM of the following variables; RER (Real Exchange Rate), Governmental Expenditures (Gov Exp.), workers' remittances receipts (REM), foreign reserves (RESERVES), and terms of trade (TOT).

As it shown in the table 5; the ECM term is significant, which means the governmental expenditures, workers' remittances receipts, foreign reserves and terms of trade have a transitory impact on RER, not only permanent impact. Significance of the error term confirms the results of the Johansen's cointegration test, it also reflects that if we insert a shock to one of the variables of the model then $32.3 \%$ will be the speed of adjustments of the disequilibrium quarterly. This is sufficient to reject any no cointegration hypothesis and confirm the presence of a stable long-run relationship between RER and its determinants and that is consistent with the previous studies $[16,18,3,19,1,23,21,11,25]$. The estimate of ECM can be explained as follows; in the absence of any other shocks, the gap between the current RER and the equilibrium one can be reached within approximately 3 quarters of the year, while in other developing countries might need shorter period of time to reach equilibrium [ 3 , $18,23]$

Also, the results in Table 5 show the adjustment coefficients for the set of variables used in the investigation along with the short run dynamics. The adjustment coefficient associated with governmental expenditures is $55.5 \%$ and significant at level $1 \%$. Also workers' remittances receipts and TOT have the short-run deviation around the equilibrium in the long-run of nearly $60 \%$.

From all the results above, it can be endorsed that government expenditures can negatively affect RER in significance, both in short-run and long-run dynamics, which is consistent with the theory $[3,16,18,20]$. When the governmental spending increases the consumption of households will also increase, causing for deficit in the balance of trade which will deteriorate RER. Ironically, this result is consistent with the empirical results of prior researches in advanced countries and it contradicts those of developing countries [1, 3], which indicated that a higher governmental spending on non-tradable goods, therefore an appreciation in RER appears. Also, the governmental spending plays a major role in economic growth in general, through covering the need of public goods which private sector fails to serve. Therefore, monitoring government expenditures have direct effect of stabilizing RER.

On other hand, the foreign reserves are highly and positively correlated to $\mathrm{RER}^{3}$, which is consistent with the literature [1], it suggests that foreign reserves -as a liquid indicator for the economy and the capacity of the central bank to stabilize the local currency- have positive impact on the domestic economic wealth. This reinforces the importance of having well-built monetary and fiscal policies in the sake of maintaining stability of RER in the short-run. In addition, one of the roles of foreign reserves is to keep competitive priced exports which enhance the investors' willingness to participate in the local markets. Also, those reserves are in need when paying the external debt.

Although the results present a weak positive correlation ${ }^{4}$, between TOT and RER, TOT has a significant short-run effect of $8.5 \%$. The theoretical research suggests that an improvement in TOT may lead to depreciation in RER. The result of this study matches the previous studies [11, 21, 18, 23]. Theoretically speaking, when the world demand increase the price of exports will increase as well, thus the economy receives more of foreign currency which appreciates the local currency.

Similarly to TOT, the correlation between workers' remittances receipts and RER are positive and weak, similarly of other researchers" results [7, 18]. In VECM results, it is shown that Workers' remittances have short run effect of nearly $60 \%$. When the remittances increase, Jordan will receive more dollars, which will appreciate RER in the long run. In Jordan -as other developing countries- those remittances are main source of foreign currencies to the economy, moreover, those cash inflows would provide the catalyst for the consumption, saving or even investments. hence, the policy makers should set a goal of attracting more of this currency source.

\section{Conclusion and Venue for Further Research}

In short, it should be obvious that an overvaluation of a currency is unfavorable for the national economy, since it deteriorates the international competitiveness. Therefore, it is crucial for the countries to be aware of the macroeconomic determinants of its RER. In this paper four macroeconomic variables are investigated to capture their effect of RER which are; government expenditures, foreign reserves, workers' remittances receipts and TOT.

The results presented in this study showed that there is a longrun causality running the determinants to RER. Being part of the

\footnotetext{
3 See table 2.

4 See table 2.
} 
fiscal policy, government expenditures have a direct effect of RER, by increasing the government spending the demand for the money will be boosted, which will cause an inflation in prices of goods and services, and that will hit RER by a drop.

However the three other variables of the study have positive and lower association with RER. Regarding the foreign reserves and in a country uses fixed exchange rate regime, the demand and supply of money may appreciate or depreciate the currency, as a result the central bank uses the foreign reserves to stabilize the exchange rate, and otherwise the country may witness the movement (inflow/outflow) of capital, all of that can be managed through the monetary policy. On other hand, when workers' remittances receipts increase the country will have more foreign currencies and that will appreciate RER over time. Finally, an improvement in TOT indicates the ability of a country to buy more imports for a given level of exports. TOT is also affected by RER, when exchange rate rises it suggests lowering the prices of the domestic goods and services, however, it may not affect the prices of the exported commodities.

Since the results of the studies showed that the macroeconomic fundamentals have significant effect on the rate of change in the actual real exchange rate, therefore there were possibilities for several reform policy actions to reduce the misalignment in real exchange rate. Of the suggestions to be provided is emphasis on the role of capital governmental expenditures in elevating the economy, and to support trade liberalization in tendency to depreciate RER. Also, policy makers should assist raising workers' remittances which promotes economic development through increasing the opportunity for household investments.

For further research, the methodology of this paper can be applied in other countries to robust and validate the results of this paper are not specific for Jordan. Also, nonlinear ARDL can be applied to capture whether there is a difference between positive and negative shocks of regressors over RER. Furthermore, a panel study for several developing countries is suggested to figure whether the results are country-specific. Moreover, a study of equilibrium real exchange rate is worth to be investigated to extend this paper and articulate recommendations for policy makers.

\section{References}

[1] Aaron, J., Elbadawi, I., \& Kahn, B. (1997). Centre for the Study of African Economies, Institute of Economics and Statistics.

[2] Aizenman, J., \& Riera-Crichton, D. (2008). Real exchange rate and international reserves in an era of growing financial and trade integration. The Review of Economics and Statistics, $90(4), 812-815$.

[3] Ajao, M. G., \& Igbekoyi, O. E. (2013). The determinants of real exchange rate volatility in Nigeria. Academic Journal of Interdisciplinary Studies, 2 (1), 459-471.

[4] Alawin, M., Sawaie, K., Al-Omar, I., \& Al-Hamdi, M. (2013). Econometric analysis for the impact of the real effective exchange rate on the Jordanian economy. European Scientific Journal, 9 (25).

[5] Amuedo-Dorantes, C., \& Pozo, S. (2004). Workers' remittances and the real exchange rate: a paradox of gifts. World development, 32 (8), 1407-1417.

[6] Barbosa, L. O. S., Jayme Jr, F. G., \& Missio, F. J. (2018). Determinants of the real exchange rate in the long-run for developing and emerging countries: a theoretical and empirical approach. International Review of Applied Economics, 32 (1), 62-83.

[7] Bashir, F., \& Luqman, A. (2014). Long run Determinants of Real Exchange Rate: An Econometric Analysis from Pakistan. Pakistan Journal of Commerce \& Social Sciences, 8 (2).

[8] Bermúdez, C., \& Dabús, C. (2018). Going under to stay on top: How much real exchange rate undervaluation is needed to boost growth in developing countries. Estudios de Economía, $45(1), 5-28$.

[9] Brzozowski, M. (2006). Exchange rate variability and foreign direct investment: consequences of EMU enlargement. Eastern European Economics, 44 (1), 5-24.

[10] Cuestas, J. C., Mourelle, E., \& Regis, P. J. (2019). Real exchange rate misalignments in CEECs: have they hindered growth? (No. wp2018-05). Bank of Estonia, 5. p1-26.

[11] Drine, I. and Rault, C. (2003). On the long run determinants of real exchange rate for developing countries: Evidence from Africa, Latin America \& Asia. William Davidson Institute Working Paper 571, 1-29.

[12] Duarte, Margarida; Restuccia, Diego; and Waddle, Andrea (2007), "Exchange Rates and Business Cycles across Countries, "Economic Quarterly, Vol. 93 No. 1, pp. 57-76.

[13] Edwards, S. (1988). Real and monetary determinants of real exchange rate behavior: Theory and evidence from developing countries. Journal of development economics, 29 (3), 311-341.

[14] Engle, R. F. and Granger, C. W. J. (1987). Co-integration and Error Correction: Representation, Estimation, and Testing. Econometrica, 55 (2), 251-276.

[15] Faini, R. (1994). Workers remittances and the real exchange rate. Journal of Population Economics, 7 (2), 235-245.

[16] Ghura, D., \&Grennes, T. J. (1993). The real exchange rate and macroeconomic performance in Sub-Saharan Africa. Journal of development economics, 42 (1), 155-174.

[17] Hassan, G. M., \& Holmes, M. J. (2013). Remittances and the real effective exchange rate. Applied Economics, 45 (35), 4959-4970.

[18] Hyder, Z., \& Mahboob, A. (2006). Equilibrium real effective exchange rate and exchange rate misalignment in Pakistan. SBP Research Bulletin, 2 (1).

[19] Insah, B., \&Chiaraah, A. (2013). Sources of real exchange rate volatility in the Ghanaian economy. Journal of Economics and international Finance, 5 (6), 232-238.

[20] Kia, A. (2013). Determinants of the real exchange rate in a small open economy: Evidence from Canada. Journal of International Financial Markets, Institutions and Money, 23, 163-178. 
[21] Lane, P. R., \& Milesi-Ferretti, G. M. (2002). Long-run determinants of the Irish real exchange rate. Applied Economics, 34 (5), 549-553.

[22] Lopez, H., Bussolo, M., \& Molina, L. (2007). Remittances and the real exchange rate. World Bank Policy Research Working Paper, (4213).

[23] Mkenda, B. K. (2001). Long-run and short-run determinants of the real exchange rate in Zambia.

[24] Narayan, P. K., \& Smyth, R. (2004). The relationship between the real exchange rate and balance of payments: empirical evidence for China from cointegration and causality testing. Applied Economics Letters, 11 (5), 287-291.
[25] Rehman, H., Jaffri, A. A. and Ahmad, I. (2010). Impact of foreign direct investment inflows on Equilibrium Real Exchange rate of Pakistan. South Asian Studies, A Research Journal of South Asian Studies, 25 (1), 125-141.

[26] Thapa, Nara (2002), "An Econometric Analysis of the Impact of Real Effective Exchange Rate on Economic Activity," Nepal, Economic Review: Occasional Paper, No. 14.

[27] Zhang, F., \&Zuohong, P. A. N. (2004). Determination of China's long-run nominal exchange rate and official intervention. China Economic Review, 15 (3), 360-365. 